\title{
Nuclear Receptor Subfamily 4 Group A Member 1
}

National Cancer Institute

\section{Source}

National Cancer Institute. Nuclear Receptor Subfamily 4 Group A Member 1. NCI

Thesaurus. Code C30088.

Nuclear receptor subfamily 4 group A member 1 (598 aa, $\sim 64$ kDa) is encoded by the human NR4A1 gene. This protein is involved in the regulation of gene expression. 